Pediat. Res. 4: 120-128 (1970)

Glucagon insulin

glucose newborn

hyperglycemia

\title{
Glucose Production and Utilization in the Newborn Puppy
}

\author{
David Kornhauser, Peter A.J. Adam and Robert Schwartz ${ }^{[26]}$ \\ Department of Pediatrics, Case Western Reserve University School of Medicine at Cleveland \\ Metropolitan General Hospital, Gleveland, Ohio, USA
}

Extract

A steady-state radioglucose dilution technique was used to determine new glucose production in six newborn (1-4 days) and two adult dogs in the postabsorptive state, and during a 90 -min glucagon infusion.

Basal new glucose production rates were 2.0 and $2.2 \mathrm{mg} / \mathrm{kg}$ body weight per minute in the adults. In contrast, basal rates in the newborn were $2-4$ times $(4.1-7.9 \mathrm{mg} / \mathrm{kg} / \mathrm{min})$ the values for the adults.

During glucagon-induced hyperglycemia in the adult, glucose production increased to 2.5 times the basal level, while plasma glucose concentration rose to a peak at $30 \mathrm{~min}$. The newborn dog responded with only a $40 \%$ increment above basal production while glucose concentration rose continuously. The adult responded with a rise in plasma insulin level but no change was observed in the newborn. The fractional rate of glucose utilization during the glucagon-induced hyperglycemia was observed to decline in newborn dogs; no decline was observed in the adults. Glucose metabolism in the newborn differs from that in the adult dog as follows: 1 ) basal glucose production and utilization per unit body weight are greater in the newborn; and 2) during glucagon-stimulated hyperglycemia the newborn adapts with less acceleration of both the production and the utilization of glucose.

\section{Speculation}

If the human newborn responds similarly to the puppy, then hepatic glucose output appears to be near maximum in order to meet basal requirements for glucose. Conditions that accelerate peripheral tissue glucose uptake will, therefore, rapidly result in hypoglycemia. Conversely, a reduction in hepatic output may result in low blood glucose concentration.

\section{Introduction}

Newborn infants in the first few hours of life frequently are observed to have abnormally low concentrations of glucose in the blood when compared with the adult $[5,20]$. This hypoglycemic period may be due to decreased glucose production, increased glucose utilization, or both. Attempts to assess the adequacy of glucose production and the rate of glucose utilization in the human newborn have been indirect and have focused on measuring changes in the concentration of glucose in the blood after administering glucose or various hormones to the infant.

Recently, Allen et al. [1] demonstrated that the physiology of carbohydrate metabolism in the newborn puppy and in the human neonate are similar. Both dispose of an acute exogenous glucose load slowly, and both exhibit a prolonged, slow response to glucagon. 
The response to glucagon indicates that glycogen stores are available in the liver and that the degradative enzymes of glycogenolysis exist and can be activated with adequate stimulation. The slow uptake of glucose suggests a lack of insulin action in the newborn. Since the mechanism for the physiological decline of blood glucose concentration in the newborn infant has not been elucidated, the following hypotheses have been proposed: attenuated response of the liver to physiological stimuli raising hepatic glucose secretion [4], inadequate hormonal control of glucose production and utilization $[4,16]$, and the presence of a relatively large noninsulin-dependent fixed requirement for glucose.

The similarity of the blood glucose responses to varied stimuli suggests that the more fundamental events of glucose production and utilization may also be similar in the newborns of these two species. Therefore, the puppy was used as an experimental model for a more direct quantitative study of these basic events in the human neonate. The present studies were designed to obtain quantitative information describing the production and utilization of glucose in the newborn puppy in the basal state and when maximally stimulated by glucagon.

\section{Methods and Materials}

Pregnant mongrel bitches were maintained in kennels and fed a standard diet for at least 2 days prior to delivery. Newborn puppies were removed from their mothers 1-4 days after spontaneous vaginal delivery and fasted for 3-3.5 h. During this period, under local anesthesia, indwelling catheters were inserted into a femoral vein and into the right external jugular vein to the level of the right heart. Catheters were maintained patent with a $100-\mu \mathrm{U} / \mathrm{ml}$ heparin-saline solution. At least $1 \mathrm{~h}$ was allowed for equilibration to basal conditions following the procedure. Temperature was monitored rectally and maintained with an infrared lamp at $36-38^{\circ}$ throughout the equilibration and experimental periods. At the beginning of the experimental period, following the method of STEELE $e t$ al. [22], $50 \mu \mathrm{Ci} / \mathrm{kg}$ of negligible amounts of glucose- $\mathrm{U}-{ }^{14} \mathrm{C}$ were injected rapidly into the femoral vein and followed with a constant infusion of glucose- $\mathrm{U}-{ }^{14} \mathrm{C}$ in saline designed to deliver an equivalent amount of radioactivity in $110 \mathrm{~min}$. Ninety minutes after the priming injection, glucagon [23] was added to the infusate in an amount sufficient to administer 2,035 $\mu$ g glucagon/ $\mathrm{kg} / \mathrm{min}$. One puppy, 3388 B, was a 150 -min control. Blood samples, $0.7 \mathrm{ml}$ in volume when insulin specimens were obtained, and $0.4 \mathrm{ml}$ otherwise, were drawn for analysis from the jugular vein cannula after clearing the heparin solution.
Two adult dogs were studied after an overnight fast. They were anesthetized with $30 \mathrm{mg} / \mathrm{kg}$ of sodium pentobarbital given intravenously. Two subcutaneous leg veins on different hind limbs were cannulated to permit a 4.0-ml sampling from one vein and infusion into the other. The experimental model also included 90-min fasting and $90-\mathrm{min}$ glucagon periods. Glucose-U-14 $\mathrm{C}$ was given at one-fifth the dosage administered to the puppies, or $10 \mu \mathrm{Ci} / \mathrm{kg}$ as a prime injection, with an identical amount infused over $110 \mathrm{~min}$. Glucagon was infused at one-tenth the puppy dose or $3.1-3.5 \mu \mathrm{g} / \mathrm{kg} /$ min. Temperature was monitored and maintained as above.

Blood samples were kept at $0^{\circ}$ until centrifuged in the cold. Aliquots of plasma for insulin determinations were removed immediately and frozen until time of assay. Glucose analyses were performed on both whole blood and plasma after protein precipitation with $0.3 \mathrm{~N}$ $\mathrm{Ba}(\mathrm{OH})_{2}$ and $5.0 \% \mathrm{ZnSO}_{4}$, in a ratio of $1: 1: 1$, of sample- $\mathrm{Ba}(\mathrm{OH})_{2}-\mathrm{ZnSO}_{4}$ [21]. The zinc sulfate used in the precipitation carried a chemically unmeasurable amount of glucose-6- ${ }^{3} \mathrm{H}$ for use as an internal standard; $0.1 \mathrm{ml}$ of a $1 \mathrm{mCi} / \mathrm{ml}, 2.7 \mathrm{mCi} / \mathrm{mg}$ glucose- $6-{ }^{3} \mathrm{H}$ solution was added to $100 \mathrm{ml}$ of the zinc sulfate solution. Puppies $3388 \mathrm{~B}$ and $3388 \mathrm{C}$ lacked this standardization. Glucose concentration was measured by a microglucose oxidase method using $25 \mu \mathrm{l}$ of Somogyi filtrate and $1.5 \mathrm{ml}$ of 1 unit of Worthington reagent diluted to $30 \mathrm{ml}$. Repetitive analysis of glucose standards showed a maximum variation in results of $4 \%$.

Glucose specific activity was measured using a minor modification of the method of BAKER et al. [3]. Glucose was separated from other compounds by thin-layer chromatography on a silica gel base. Fifty-microliter samples of Somogyi filtrates were spotted, 3-4 $\mu \mathrm{l}$ at a time, and migrated in a $n$-butanol-ethanol-acetic acid solvent system. The $R_{F}$ was $0.44-0.56$ with the band from 40 to $60 \mathrm{~mm}$ being eluted with $70 \%$ ethanol after a $100-\mathrm{mm}$ migration. Recoveries of $95-100 \%$ of spotted standards were obtained. One aliquot of the eluate was analyzed for glucose using an alcoholic dilution of the Worthington glucose oxidase reagent. Analysis of glucose standards after thin-layer chromatography yielded results accurate to $\pm 3 \%$. The ${ }^{14} \mathrm{C}$ and ${ }^{3} \mathrm{H}$ counts in another aliquot were measured with a liquid scintillation counter. A scintillant comprised of 2,5-diphenyloxazole (PPO), 1,4-bis[2-(5-phenyloxazolyl)]-benzene (POPOP), naphthalene, and methanol dissolved in 1,4-dioxane was used. Uniform quenching was observed in all specimens. Negligible ${ }^{3} \mathrm{H}$ counts appeared in the ${ }^{14} \mathrm{G}$ channel while $23 \%$ of ${ }^{14} \mathrm{C}$ counts appeared in the tritium channel. Activity was 10-20 times background in both channels; specimens were counted for $20 \mathrm{~min}$. Specific activity was determined by dividing the number of ${ }^{14} \mathrm{C}$ counts by the glucose. Calculations 
of glucose production using glucose specific activities determined from the plasma and whole blood of the same dog differed by about $10 \%$.

Plasma insulin concentration was determined by immunoassay using a modification of the double antibody precipitation technique of MORGAN and LAZARow [15]. Guinea pig anti-porcine insulin serum and rabbit anti-guinea pig gamma globulin serum were used in the precipitation. Porcine insulin standards were employed. The guinea pig anti-insulin serum reacted identically to canine and porcine insulin. The variance of the insulin assay in the laboratory, expressed as mean $\pm \mathrm{SD}$, was as follows: $5 \pm 0.9,10 \pm 1.1$, and $40 \pm 2.0 \mu \mathrm{U} / \mathrm{ml}$.

\section{Calculations}

StEELE et al. [22] have derived the equation describing the glucose specific activity curve during the infusion of trace amounts of labeled glucose following a priming injection of tracer glucose. Assuming a well-mixed pool of body glucose in a steady state, once the influence of the priming dose is lost, the rate of production of glucose (g) (in $\mu \mathrm{g}$ of glucose per minute) is equal to the infusion rate $\left(\mathrm{F}\right.$ ) (in $\mathrm{cpm}$ of ${ }^{14} \mathrm{C}$ glucose on a negligible amount of glucose), divided by the glucose specific activity (SA) (in ${ }^{14} \mathrm{C}$ glucose $\mathrm{cpm} / \mu \mathrm{g}$ glucose) $: \mathrm{g}=\mathrm{F} / \mathrm{SA}$. STEele et al. [22] observed that in adult dogs the priming dose does not affect glucose specific activity after about $60 \mathrm{~min}$. In the results below, the average rate of production of glucose over a time interval (g), was determined during the steady state of glucose specific activity by dividing the infusion rate (F) by the average glucose specific activity (SA), this average being computed from four points $(60-90 \mathrm{~min}$ for the control period, and $150-180 \mathrm{~min}$ for the period of glucagon infusion).

Body surface area was calculated from body weight using the formulas of Cowgill and Drabkin [7] for young (Thomas' data) and old (Stewart's data) dogs.

\section{Results}

Six puppies, two from each of three litters, and two adults were studied. Puppy $3388 \mathrm{~B}$ was a 150 -min fasting control. All other puppies and the two adults were studied for $180 \mathrm{~min}$, a 90 -min control period followed by a 90 -min glucagon infusion period. At the end of the experiment the total period of fasting for the puppies was $6-6.5 \mathrm{~h}$ and for the adult dogs it was $30-32 \mathrm{~h}$.

The plasma glucose responses during the experimental periods are shown in table $I$ and figures 1 and 2 for a representative puppy and an adult dog. In both newborns and adults, the fasting plasma glucose concentration remained constant, or as in the case of puppy $3388 \mathrm{~B}$, declined over the 150 -min period. In two puppies, $3381 \mathrm{~A}$ and $2 \mathrm{D}$, the control values were considerably higher than the other fasting samples. This may not represent basal conditions and may have been induced by handling the animals prior to sampling and injection of tracer.

Plasma glucose concentrations increased during

Table 1 . Venous plasma glucose concentration ${ }^{1}$ during the infusion of tracer glucose and glucagon

\begin{tabular}{|c|c|c|c|c|c|c|c|c|c|c|c|c|c|c|}
\hline \multirow[t]{2}{*}{ Dog no. } & \multirow{2}{*}{$\begin{array}{l}\text { Age, } \\
\text { days }\end{array}$} & \multirow{2}{*}{$\begin{array}{l}\text { Wt, } \\
\mathrm{kg}\end{array}$} & \multirow{2}{*}{$\begin{array}{c}\text { Glu- } \\
\text { cagon }^{2} \text {, } \\
\mu \mathrm{g} / \mathrm{kg} / \\
\mathrm{min}\end{array}$} & \multicolumn{11}{|c|}{ Minutes after prime injection of glucose- $\mathrm{U}^{-14} \mathrm{C}$} \\
\hline & & & & 0 & 60 & 70 & 75 & 80 & 90 & 120 & 135 & 150 & 165 & 180 \\
\hline & & & & & & & & & & \multicolumn{5}{|c|}{ __ Glucagon infusion } \\
\hline $3388 \mathrm{~B}$ & 1 & 0.25 & 0 & 106 & 102 & \multicolumn{3}{|c|}{89} & 96 & 83 & 81 & 73 & - & 一 \\
\hline $3388 \mathrm{C}$ & 2 & 0.25 & 32 & 132 & 128 & \multicolumn{3}{|c|}{130} & 135 & 167 & 171 & 170 & 170 & 185 \\
\hline $3381 \mathrm{~A}$ & 1 & 0.26 & 32 & 130 & 113 & \multicolumn{2}{|l|}{114} & 111 & 120 & 166 & 171 & 201 & 200 & 218 \\
\hline $3381 \mathrm{C}$ & 4 & 0.26 & 33 & 77 & 79 & \multicolumn{2}{|l|}{74} & 80 & 80 & 115 & 129 & 139 & 149 & 160 \\
\hline $2 \mathrm{D}$ & 2 & 0.33 & 27 & 143 & 116 & \multicolumn{2}{|l|}{111} & 111 & 121 & 205 & 237 & 309 & 296 & 309 \\
\hline $2 \mathrm{E}$ & 3 & 0.38 & 22 & 105 & 97 & \multicolumn{2}{|l|}{100} & 94 & 98 & 115 & 130 & 125 & 134 & 154 \\
\hline 4033 & Adult & 6.2 & 3.3 & 102 & 107 & \multicolumn{2}{|l|}{116} & 112 & 111 & 276 & 264 & 261 & 234 & 231 \\
\hline 4071 & Adult & 6.1 & 3.3 & 83 & 84 & \multirow{2}{*}{\multicolumn{2}{|c|}{86}} & 90 & 87 & 202 & 161 & - & 140 & 109 \\
\hline & & & & & & & & & & & & & \multicolumn{2}{|c|}{$\left(171^{\prime}\right)\left(202^{\prime}\right.$} \\
\hline
\end{tabular}

${ }^{1}$ In milligrams per $100 \mathrm{ml}$ of plasma.

${ }^{2}$ Infusion begun after 90 -min sample. 
glucagon infusion. In all five puppies the glucose concentration increased throughout the infusion so that at the end of the experiment, plasma glucose was at its highest level. In contrast, in both adult dogs, plasma glucose concentration was greatest at the earliest sample, $30 \mathrm{~min}$ after the beginning of the infusion, and it declined during the remaining hour of the infusion. The highest plasma glucose concentrations during the infusion ranged from 50 to $188 \mathrm{mg} / 100 \mathrm{ml}$ higher than the last fasting sample in the newborns and 115 and $165 \mathrm{mg} / 100 \mathrm{ml}$ higher than the last fasting sample in the adults.

Table II and figures 1 and 2 demonstrate that the plasma glucose specific activity reached a steady state during the fasting period and again during the glucagon infusion. There was clearly a reduction in the specific activity during the glucagon infusion for both newborns and adults.

If isotopic glucose is metabolized identically to unlabeled glucose, changes in glucose utilization cannot induce changes in the glucose specific activity. With the constant infusion of tracer, the rate of production of glucose is given by $\mathrm{F} / \mathrm{SA}$ even when the plasma glucose concentration is changing. The values for the production of glucose referred to the metabolic reference standards of body weight and body surface area are shown in table III. Although the series was small, there was no apparent correlation between the age of the puppy and the magnitude of production. The results appeared to be paired by litters; puppies $3388 \mathrm{~B}$ and $3388 \mathrm{G}$ had similar rates of production as did puppies $3381 \mathrm{~A}$ and $3381 \mathrm{C}$, and puppies $2 \mathrm{D}$ and $2 \mathrm{E}$. The two adult values were alike.

On a weight basis, the newborns produced more than twice as much glucose in the fasting state than did the adults; during glucagon stimulation the puppies also achieved higher production rates. Normalizing the results to body surface area, adults and newborns produced comparable amounts of glucose during fasting but the adults were able to achieve higher rates during the infusion of hormone. The ratio of glucagonstimulated production to fasting production is invariant to changes in the metabolic reference standard. In the glucagon-stimulated state, glucose production in the newborns was about $140 \%$ of the fasting amount, while in the adults the ratio was approximately 2.5 ; the puppies could only increase fasting production by $40 \%$ whereas the adults could produce an increment of $150 \%$.

Plasma insulin values during the fasting period and during the glucagon infusion are shown in table IV. Fasting insulin concentrations were similar in all dogs except one adult, 4033, which had slightly elevated values. Insulin concentrations did not rise during the infusion of tracer. During the glucagon infusion, plasma insulin in the puppies rose $2-5 \mu \mathrm{U} / \mathrm{ml}$. These values were not significantly different from those of the fasting period. Insulin concentrations rose significantly in the

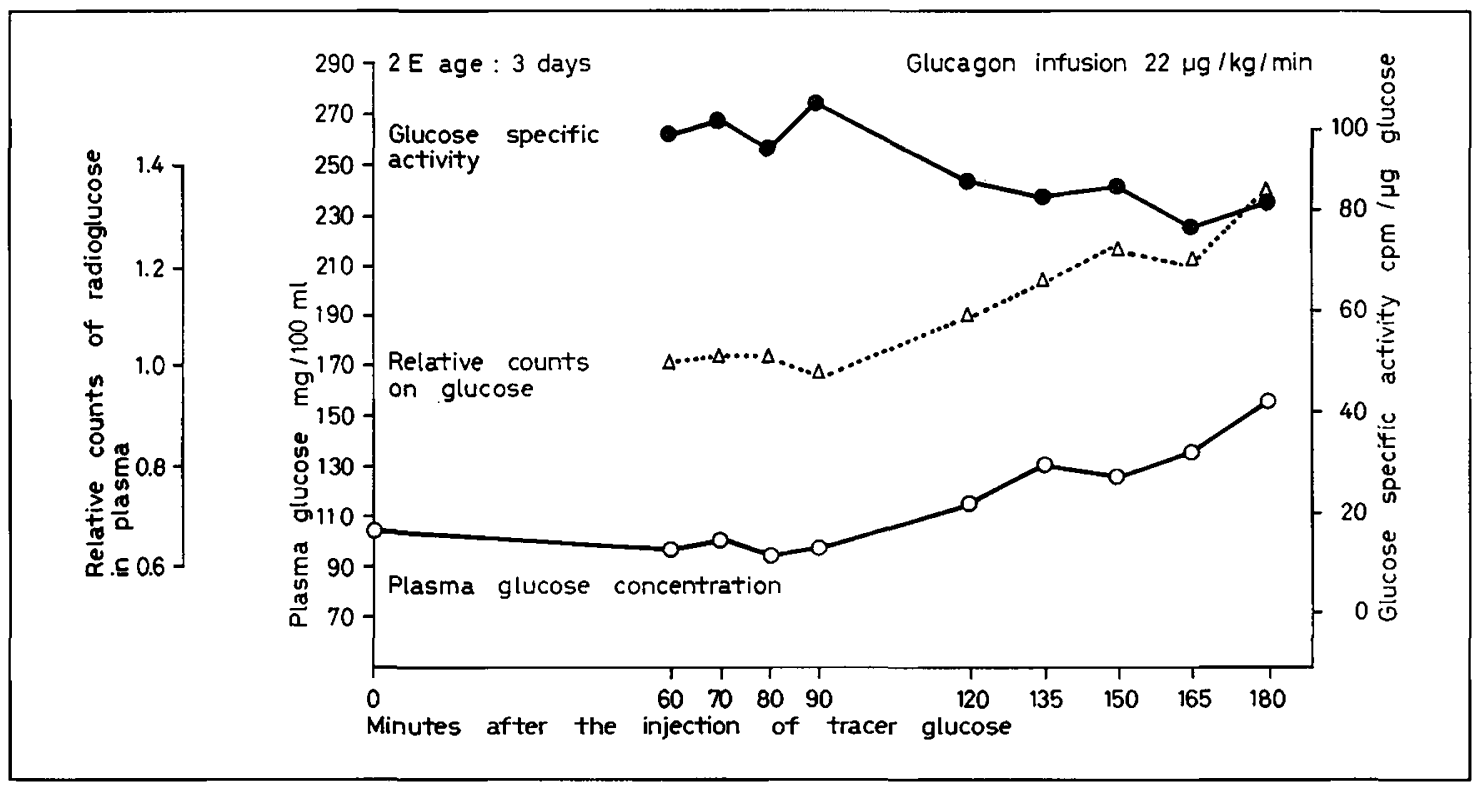

Fig. 1. Plasma glucose concentration, glucose specific activity, and relative counts of radioglucose in plasma during the infusion of tracer glucose and glucagon in a representative newborn dog. 
adult dogs during the glucagon infusion. In one, the concentration was maximal at the termination of the experiment $(110 \mu \mathrm{U} / \mathrm{ml})$, while in the other an early peak was achieved $(70 \mu \mathrm{U} / \mathrm{ml})$ with a decline to the fasting level by the end of the experiment.

For both the newborns and the adults, the data on the sustained production of glucose and on glucose concentrations can be used to estimate the relative magnitude of the elevation in utilization maintained during the glucagon infusion. In the puppies, glucose production was sustained at $140 \%$ of the control level during the infusion of hormone. The plasma glucose concentration continued to rise, however, indicating that utilization was less than production, and hence, less than $140 \%$ of the fasting amount. In the adult dogs, the plasma glucose concentration was falling

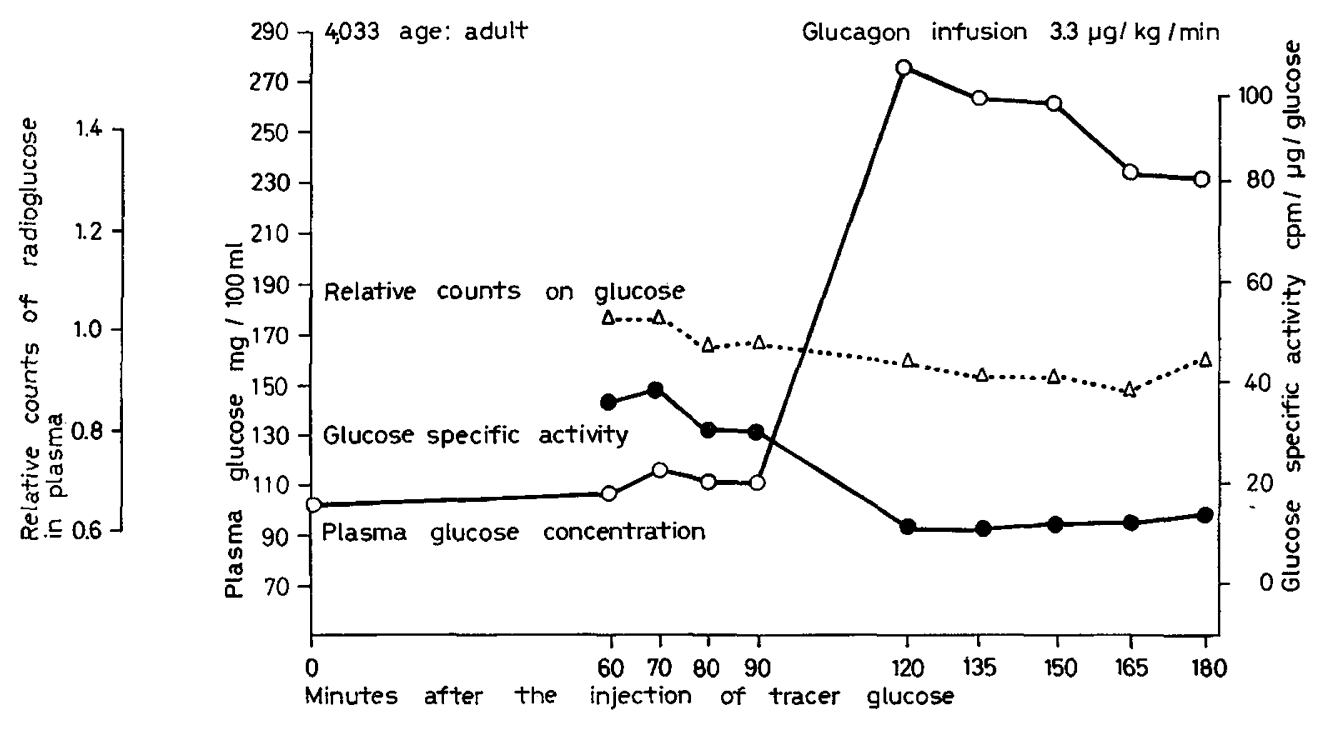

Fig.2. Plasma glucose concentration, glucose specific activity, and relative counts of radioglucose in plasma during the infusion of tracer glucose and glucagon in a representative adult dog.

Table II. Plasma glucose specific activity ${ }^{1}$ before and after glucagon

\begin{tabular}{|c|c|c|c|c|c|c|c|c|c|c|c|}
\hline \multirow[t]{2}{*}{ Dog no. } & \multirow{2}{*}{$\begin{array}{l}\text { Age, } \\
\text { days }\end{array}$} & \multicolumn{10}{|c|}{ Minutes after prime injection of glucose- $\mathrm{U}^{-14} \mathrm{C}$} \\
\hline & & 60 & 70 & 75 & 80 & 90 & 120 & 135 & 150 & 165 & 180 \\
\hline $3388 \mathrm{~B}$ & 1 & 90 & & 87 & & 89 & 92 & 93 & 100 & & \\
\hline $3388 \mathrm{C}^{2}$ & 2 & 63 & & 64 & & 61 & 51 & 49 & 47 & 50 & 48 \\
\hline $3381 \mathrm{~A}$ & 1 & 114 & 126 & & 127 & 122 & 105 & 88 & 103 & 78 & 80 \\
\hline $3381 \mathrm{~B}$ & 4 & 124 & 120 & & 110 & 111 & 84 & 83 & 88 & 86 & 81 \\
\hline $2 \mathrm{D}$ & 2 & 75 & 85 & & 86 & 92 & 52 & 53 & 50 & 49 & 49 \\
\hline $2 \mathrm{E}$ & 3 & 96 & 99 & & 93 & 102 & 86 & 83 & 85 & 77 & 82 \\
\hline 4033 & Adult & 37 & 39 & & 31 & 31 & 11 & 11 & 12 & 12 & 14 \\
\hline 4071 & Adult & 39 & 41 & & 41 & 41 & 14 & 18 & - & $\begin{array}{c}16 \\
\left(171^{\prime}\right)\end{array}$ & $\begin{array}{c}24 \\
\left(202^{\prime}\right)\end{array}$ \\
\hline
\end{tabular}

1 In counts per minute per microgram glucose.

${ }^{2}$ Specific activity was determined from whole blood. 
Table III. Glucose production

\begin{tabular}{ccccccc}
\hline Dog no. & $\begin{array}{c}\text { Age, } \\
\text { days }\end{array}$ & Fasting & $\begin{array}{c}\text { Glucagon } \\
\text { stimulated } \\
\mathrm{mg} / \mathrm{kg} / \mathrm{min}\end{array}$ & Fasting & $\begin{array}{c}\text { Glucagon } \\
\mathrm{mg} / \mathrm{m}^{2} / \mathrm{min}\end{array}$ & $\begin{array}{c}\text { Glucagon } \\
\text { stimulated }\end{array}$ \\
\hline $3388 \mathrm{~B}$ & 1 & 7.4 & - & 48 & - & Fasting \\
$3388 \mathrm{C}$ & 2 & 7.9 & 10.1 & 52 & 67 & 1.3 \\
$3381 \mathrm{~A}$ & 1 & 4.1 & 5.5 & 28 & 37 & 1.3 \\
$3381 \mathrm{C}$ & 4 & 4.6 & 6.3 & 31 & 42 & 1.4 \\
$2 \mathrm{D}$ & 2 & 5.0 & 8.2 & 36 & 59 & 1.6 \\
$2 \mathrm{E}$ & 3 & 4.4 & 5.2 & 33 & 39 & 1.2 \\
4033 & Adult & 2.0 & 5.4 & 38 & 102 & 2.7 \\
4071 & Adult & 2.2 & 4.8 & 41 & 90 & 2.2 \\
\hline
\end{tabular}

Table IV. Plasma insulin concentration ${ }^{1}$ during the fasting state and during glucagon infusion

\begin{tabular}{ccrrrr}
\hline Dog no. & $\begin{array}{l}\text { Age, } \\
\text { days }\end{array}$ & \multicolumn{3}{c}{$\begin{array}{c}\text { Minutes after primeinjection } \\
\text { of glucose-U_14 C }\end{array}$} \\
\cline { 2 - 6 } & & 0 & 90 & 150 & 180 \\
\hline & & Fasting & \multicolumn{2}{c}{$\begin{array}{c}\text { Glucagon } \\
\text { infusion }\end{array}$} \\
3388 C & 2 & 7 & 6 & 12 & 11 \\
3381 A & 1 & 10 & 10 & 10 & 12 \\
3381 C & 4 & 6 & 6 & 10 & 8 \\
2D & 2 & 8 & 6 & 10 & 10 \\
2E & 3 & 7 & 6 & 7 & 8 \\
4033 & Adult & 18 & 15 & 82 & 110 \\
4071 & Adult & 8 & 10 & 70 & 12 \\
& & & & $\left(135^{\prime}\right)$ & $\left(202^{\prime}\right)$ \\
\hline
\end{tabular}

1 Referred to a porcine standard, in microunits per milliliter. while glucose production was sustained at $250 \%$ of the rate during the control period. Therefore, utilization of glucose during the glucagon infusion must have been greater than 2.5 times the fasting figure.

In table $\mathrm{V}$, the concentration of plasma glucose radioactivity $(\mathrm{cpm} / \mathrm{ml})$ is compared with the mean fasting level of labeled glucose from 60 to $90 \mathrm{~min}$ of glucose- $\mathrm{U}-{ }^{14} \mathrm{C}$ in glucose $(\mathrm{cpm} / \mathrm{ml})$ divided by the mean fasting concentration of ${ }^{14} \mathrm{C}$ in glucose $(\mathrm{cpm} / \mathrm{ml})$. These levels of labeled glucose were determined using an internal standard of glucose- $6{ }^{3} \mathrm{H}$. Since no such standard was employed with pups $3388 \mathrm{~B}$ or $3388 \mathrm{C}$, the data are not presented for them.

With constant infusion of labeled glucose the concentration of glucose $-{ }^{14} \mathrm{C}$ will vary inversely with both the volume of distribution of the radioactive glucose and its fractional disposal. Therefore, an elevation in the plasma level of labeled glucose while volume increases or remains constant represents a minimal estimate of a decline in the fractional utilization of glucose.

Table $V$. Relative counts of radioglucose in plasma ${ }^{1}$

\begin{tabular}{|c|c|c|c|c|c|c|c|c|c|c|}
\hline \multirow[t]{2}{*}{ Dog no. } & \multirow{2}{*}{$\begin{array}{l}\text { Age, } \\
\text { days }\end{array}$} & \multicolumn{9}{|c|}{ Minutes after prime injection of glucose- $U-{ }^{14} \mathrm{G}$} \\
\hline & & 60 & 70 & 80 & 90 & 120 & 135 & 150 & 165 & 180 \\
\hline & \multicolumn{5}{|c|}{ Fasting } & \multicolumn{5}{|c|}{ Glucagon infusion } \\
\hline $3381 \mathrm{~A}$ & 1 & 0.92 & 0.99 & 1.00 & 1.09 & 1.30 & 1.15 & 1.43 & 1.24 & 1.33 \\
\hline $3381 \mathrm{C}$ & 4 & 1.05 & 1.00 & 0.97 & 0.99 & 1.07 & 1.20 & 1.32 & 1.36 & 1.43 \\
\hline $2 \mathrm{D}$ & 2 & 0.97 & 0.95 & 0.99 & 1.09 & 1.07 & 1.16 & 1.36 & 1.34 & 1.24 \\
\hline $2 \mathrm{E}$ & 3 & 1.00 & 1.01 & 1.01 & 0.98 & 1.09 & 1.16 & 1.22 & 1.20 & 1.33 \\
\hline 4033 & Adult & 1.03 & 1.03 & 0.97 & 0.98 & 0.94 & 0.91 & 0.91 & 0.88 & 0.94 \\
\hline 4071 & Adult & 0.99 & 0.99 & 1.01 & 1.02 & 0.90 & 1.02 & - & $\begin{array}{c}0.68 \\
\left(171^{\prime}\right)\end{array}$ & $\begin{array}{c}0.58 \\
\left(202^{\prime}\right)\end{array}$ \\
\hline
\end{tabular}

${ }^{1}$ Glucose $(\mathrm{cpm} / \mathrm{ml})$ per unit volume of plasma expressed as a fraction of the mean glucose $(\mathrm{cpm} / \mathrm{ml})$ per unit volume of plasma during fasting. 
In all newborn and adult dogs, the concentration of glucose- ${ }^{14} \mathrm{C}$ in plasma remained constant after the influence of the priming dose was lost (figs. 1 and 2, table V). In the four puppies studied, however, labeled glucose gradually accumulated during the glucagon infusion, and by the end of the experiment averaged $133 \%$ (range 124-143\%) of control levels. Since the plasma insulin concentration in the puppies was relatively constant, the virtual volume of distribution of glucose may have remained constant or increased only slightly. If this assumption is true, then, by the end of the glucagon infusion, the fractional disposal of glucose had declined to $\frac{1.00}{1.33}=0.75$ (range $70-80 \%$ ) of that during the fasting state.

In the two adult dogs, however, the plasma glucose$\mathrm{U}-{ }^{14} \mathrm{C}$ concentration declined maximally by 12 and $42 \%$. Concomitantly, there was a large elevation in plasma insulin concentration. Since both the apparent volume of distribution and the fractional disposal of glucose may have increased under these conditions, glucose disposal may not be estimated from the decline in the level of labeled glucose.

\section{Discussion}

This experimental model was chosen to minimize errors in the calculation of new glucose production. Steele, Altszuler, and co-workers $[2,22]$ have discussed the magnitude of error resulting from interpool mixing and the recirculation of label occurring in experiments in adult dogs using this same model. While the isotope dilution technique measures new glucose produced throughout the entire body, only the liver and kidney are capable of producing glucose and releasing it into the extracellular compartment. Recently, Jonsson and MADISON [11] demonstrated that the kidneys of fasted adult dogs extract glucose from arterial blood. Thus, the determination of endogenous glucose production by tracer techniques is primarily a measurement of hepatic glucose production (HGP). The HGP differs from net hepatic glucose output (NHGO) by the amount of glucose utilized by the liver, hepatic glucose utilization. MADISON et al. [14] have discussed at length the conditions under which HGP approximates NHGO and have demonstrated that in the fasting state there is a close correlation between the two variables [13]

Although the consumption of metabolic fuel may be referred to the surface area in a basal state, the change in blood glucose concentration following hormonal stimulation of the liver is a function of both the increased rate of production of glucose relative to total utilization, and the virtual volume of distribution of the glucose. Thus, while the results were tabulated with both body weight and body surface area as standards, the results arbitrarily are discussed using the data normalized to body weight only.

The values of 2.0 and $2.2 \mathrm{mg} / \mathrm{kg} / \mathrm{min}$ for glucose production rates in fasting adult dogs obtained in these experiments are in close agreement with the data of DE BoDo et al. [10] who studied 12 dogs fed a mixed diet containing $38 \%$ of the total calories as carbohydrate, and who measured the postabsorptive glucose production rate at $2.40 \pm 0.15 \mathrm{mg} / \mathrm{kg} / \mathrm{min}$ (mean $\pm \mathrm{SEM}$ ). In comparison, the basal production rates of the puppies were $4.1-7.9 \mathrm{mg} / \mathrm{kg} / \mathrm{min}$, or 2-4 times the adult rates.

A constant glucagon stimulus initiated a rapid phase of hepatic glucose output followed by a constant output above control levels. The glucagon infusion generally created greater sustained increments in production in the adults than in the newborns. The puppies, however, maintained higher prolonged production rates on a weight basis. The ratio of the glucagon-stimulated production rate to the fasting rate was 2.5 in the adults and 1.4 in the newborns. Thus, if the glucagon-stimulated rate represents the maximal or near maximal capacity of the liver to maintain glucose production from glycogen, the data indicate that, in canines in the fasting state, the newborn liver may be functioning much closer to its capacity than is the adult liver. Total glucose production, however, would include not only glucose derived from glycogen but also that from gluconeogenesis. Whether the latter is increased by glucagon under the conditions of this study is unknown.

During the first 4 days of life, liver glycogen content of the puppy declined from 93.4 to $12.0 \mathrm{mg} / \mathrm{g}$ of liver. These levels contrast with the adult level of $35.5 \mathrm{mg} / \mathrm{g}$ of liver [1]. Thus, in the newborn, liver concentration of glycogen decreases from 2.5 times adult levels to less than $50 \%$ of adult levels despite normal suckling.

Fasting insulin concentrations in the two age groups were similar. During the glucagon infusion, insulin levels rose within the initial sampling period in the adults. Glucagon, per se, is a potent stimulus to insulin secretion as is the hyperglycemia produced $[8,12,19]$. The slope and magnitude of the insulin and blood sugar response obtained in the adult dog resemble the data reported by GROGKForD et al. [8] obtained in human adults during a 3 -h glucagon infusion. In the puppy, glucagon infusion with the attendant hyperglycemia elicited a minimal rise in insulin levels. Thus, in newborn dogs, insulin secretion in response to glucagon or hyperglycemia is blunted or delayed.

The decline in the fractional utilization of glucose in the newborns at elevated glucose concentrations (see Results, table V) can be understood if the body is viewed as being composed of two types of tissues: the 
first, exemplified by brain, where utilization of glucose is relatively fixed and independent of insulin [17, 18]; the second, exemplified by skeletal muscle and adipose tissue, where utilization of glucose is stimulated by insulin [9, 17]. During fasting states the major portion of the glucose produced is used by insulin-independent tissues. Normally, as in the adult dog during hyperglycemia, insulin is secreted, and consequently, there is an increase in utilization of glucose by the stimulated tissues. Thus, there is an increase in the total amount of glucose utilized and the fractional rate of utilization may remain the same or increase.

When insulin is not secreted in response to hyperglycemia, however, as in the newborn dog, there may be only a small increase in glucose uptake by insulindependent tissues secondary to the increased glucose concentration, and the capacity to use glucose may be increased very little. Thus, the amount of glucose utilized remains virtually unchanged while the plasma glucose pool increases and the fractional rate of glucose utilization is thus decreased. This phenomenon would occur in postprandial states, following intravenous infusion of glucose or when glucose production is stimulated by exogenous hormones. It follows from the above that glucose disappearance rates measured by intravenous glucose tolerance tests in newborns would be decreased compared with rates measured with isotopic glucose at normoglycemia.

\section{Summary}

Previous studies in the puppy have demonstrated a slow glucose disappearance after an acute glucose injection, as well as a slow progressive rise in glucose concentration after a single injection of glucagon. These observations suggested a diminished peripheral tissue response to glucose loading. The present studies demonstrated that the newborn puppy has a high basal glucose production rate compared with the adult on the basis of body weight. Furthermore, under conditions of maximal glucagon stimulation, the puppy was unable to increase his glucose output as effectively as the adult. The implications of these observations are that the liver and other tissues of the newborn do not adapt rapidly to a variety of altered physiologic states.

\section{References and Notes}

1. Allen, D.T.; Kornhauser, D. and Schwartz, R.: Glucose homeostasis in the newborn puppy. Amer.J. Dis. Child. 112: 343 (1966).

2. Altszuler, N.; Steele, R.; Rathgeb, I. and de
BoDo, R. C.: Glucose metabolism and plasma insulin level during epinephrine infusion in the dog. Amer. J. Physiol. 212: 677 (1967).

3. Baker, N.; Huebotter, R.J. and Schotz, M.Z.: Analysis of glucose- $\mathrm{C}^{14}$ in tissues using thin-layer chromatography. Analyt. Biochem. 10: 227 (1965).

4. Bowie, M.D.; Mulligan, P.B. and SGhwartz, $R$.: Intravenous glucose tolerance in the normal newborn infant: The effects of a double dose of glucose and insulin. Pediatrics 31: 590 (1963).

5. Cornblath, M.; Ganzon, A.F.; Nigolopoulas, D.; Baens, G.S.; Hollander, R.J.; Gordon, M. H. and Gordon, H. H. : Studies of carbohydrate metabolism in the newborn infant. III. Some factors influencing the capillary blood sugar and the response to glucagon during the first hours of life. Pediatrics 27: 378 (1961).

6. Cornblath, M.; Wybregt, S.H. and Baens, G.S. : Studies of carbohydrate metabolism in the newborn infant. VII. Tests of carbohydrate tolerance in premature infants. Pediatrics 32: 1007 (1963).

7. Cowgill, G.R. and Drabkin, D.L.: Determinations of a formula for the surface area of the dog together with a consideration of formulae available for other species. Amer.J.Physiol. 81: 36 (1927).

8. Crockford, P.M.; Porte, D., Jr.; Wood, F.C. and Williams, R.H.: Effect of glucagon on serum insulin, plasma glucose and free fatty acids in man. Metabolism 15: 114 (1966).

9. Grofford, O.B. and Renold, A.E.: Glucose uptake by incubated rat epididymal adipose tissue. J.biol. Chem. 240: 14 (1965).

10. deBodo, R. G.; Steele, R.; Altszuler, N.; DunN, A. and Bishop, J.S.: Effects of insulin on hepatic glucose metabolism and glucose utilization by tissues. Diabetes 12: 16 (1963).

11. Jonsson, A. and Madrson, L. L.: In vivo role of the kidney in blood glucose homeostasis during stimulation of renal gluconeogenesis. Diabetes 16: 507 (1967).

12. Ketrerer, H.; Eisentraut, A.M. and Unger, R.H. : Effect upon insulin secretion of physiologic doses of glucagon administered via the portal vein. Diabetes 16: 283 (1967).

13. Lecoce, F.R.; Mebane, D. and Madison, L.L.: The acute effect of hydrocortisone on hepatic glucose output and peripheral glucose utilization. J.clin. Invest. 43: 237 (1964).

14. Madison, L.L.; Mebane, D.; Lecoce, F.R. and Combes, B.: Physiological significance of the secretion of endogenous insulin into the portal circulation. V. The quantitative importance of the liver in the disposition of glucose loads. Diabetes 12: 8 (1963).

15. Morgan, C.R. and Lazarow, A.: Immunoassay 
of insulin: Two antibody system. Diabetes 12: 115 (1963).

16. Mulligan, P.B. and Schwartz, R.: Hepatic carbohydrate metabolism in the genesis of neonatal hypoglycemia: Effects of the administration of epinephrine, glucagon, and galactose. Pediatrics 30: 125 (1962).

17. Park, C.R.; Johnson, L.H.; Wright, J.H., Jr. and BAtsel, H.: Effect of insulin on transport of several hexoses and pentoses into cells of muscle and brain. Amer. J. Physiol. 191: 13 (1957).

18. Renold, A.E.; Ashmore, J. and Hastings, A.B.: Regulation of carbohydrate metabolism in isolated tissues. Vitamins Hormones, N.Y. 14: 139 (1956).

19. Samols, E.; MArri, G. and Marks, V.: Promotion of insulin secretion by glucagon. Lancet $i i: 415$ (1965).

20. Shelley, H.J. and Neligan, G. A.: Neonatal hypoglycemia. Brit.med.Bull. 22: 34 (1966).

21. Somogyi, M.: Determination of blood sugar. J. biol. Ghem. 160: 69 (1945).
22. Steele, R.; Wall, J.S.; DeBodo, R. G. and AltszULER, N.: Measurement of size and turnover rate of body glucose pool by the isotope dilution method. Amer.J. Physiol. 187: 15 (1956).

23. Obtained from Eli Lilly and Company, Indianapolis, Ind., glucagon for injection. Glucagon $\cdot \mathrm{HCl}$ was diluted in infusate instead of supplied diluent.

24. This work was submitted in partial fulfillment for the degree of Medical Doctor by David Kornhauser.

25. Aided by National Institute of Child Health and Human Development Grant no.HD 03290, and National Institute of Arthritis and Metabolic Diseases Training Grant no.5-TI-AM-5356. Peter A.J. ADAM was formerly trainee in pediatric metabolism, National Institute of Arthritis and Metabolic Diseases Grant no. 5-T1-AM-5356.

26. Requests for reprints should be addressed to: RoBERT Schwartz, M.D., Department of Pediatrics, Cleveland Metropolitan General Hospital, 3395 Scranton Road, Gleveland, OH 44109 (USA).

27. Accepted for publication August 28, 1969. 